\title{
Analisis Maqasid Syariah Jasser Auda Terhadap Counter Legal Draft Kompilasi Hukum Islam
}

\section{Muhammad Ali Murtadlo}

Institut Agama Islam Negeri Ponorogo

alimurtadlo@iainponorogo.ac.id

Abstract: Islamic law transformative bid is made to replace the Islamic Law Compilation (KHI) in the form of Counter Legal Draft Compilation of Islamic Law (CLD-KHI), attracted the attention of academics, scholars and jurists of Islam in Indonesia. Many of those who reject and not infrequently also agree with the offer. This formulation is a challenge to bring order to respect Indonesia by Islamic law to all national character, culture and progress in democratization and upholding human rights, including women's rights. This study aims to answer the question (a) how is the legal istinbath method used in formulating the Counter Legal Draft Compilation of Islamic Law? (b) What is the formulation of the Counter Legal Draft Compilation of Islamic Law from the perspective of Jasser Auda's sharia maqasid? Library research using qualitative approach suggests that (a) the CLD-KHI is a legal draft in the form of provisions, so that in the process of its formulation is done through a procedural step that is done gradually, systematically, and involve several competent authority (b) Formulation of family law Islam offered in CLD-KHI in law istinbath method is not contrary to the concept of maqasid syariah Jasser Auda. However, the application instead of KHI still hindered political factor, because there are chapters that are considered controversial.

Keywords: Compilation of Islamic Law, CLD-KHI, Maqasid Syariah Jasser Auda

Abstrak: Tawaran hukum Islam transformatif yang dibuat untuk menggantikan Kompilasi Hukum Islam (KHI) dalam bentuk Counter Legal Draft Kompilasi Hukum Islam (CLD-KHI), menarik perhatian 
para akademisi, sarjana dan ahli hukum Islam di Indonesia. Banyak dari mereka yang menolak dan tidak jarang juga setuju dengan tawaran itu. Rumusan ini merupakan tantangan untuk memunculkan tatanan syariah Islam yang menghormati Indonesia dengan semua karakter nasional, budaya dan kemajuan dalam demokratisasi dan penegakan hak asasi manusia, termasuk hak-hak perempuan. Penelitian ini bertujuan untuk menjawab pertanyaan (a) bagaimana metode istinbath hukum yang digunakan dalam merumuskan Counter Legal Draft Kompilasi Hukum Islam? (b) Bagaimana rumusan Counter Legal Draft Kompilasi Hukum Islam ditinjau dari perspektif maqasid syariah Jasser Auda? Penelitian pustaka dengan menggunakan pendekatan kualitatif ini menunjukkan bahwa (a) CLD-KHI merupakan legal draft yang berbentuk pasal-pasal, sehingga dalam proses perumusannya dilakukan melalui langkah prosedural yang dilakukan bertahap, sistematis, dan melibatkan beberapa pihak yang berkompeten (b) Rumusan hukum keluarga Islam yang ditawarkan dalam CLD-KHI dalam metode istinbath hukum tidak bertentangan dengan konsep maqasid syariah Jasser Auda. Namun, dalam penerapannya sebagai pengganti KHI masih terhalang faktor politik, karena terdapat pasalpasal yang dianggap kontroversial.

Kata Kunci: Kompilasi Hukum Islam, CLD-KHI, Maqasid Syariah Jasser Auda

\section{PENDAHULUAN}

Tawaran hukum Islam transformatif yang disusun untuk menggantikan Kompilasi Hukum Islam (KHI) menarik perhatian kalangan akademisi, ulama dan pakar hukum Islam. Banyak yang kontra dan tak jarang pula yang setuju dengan tawaran tersebut. Pasalnya, dalam rumusan yang diberi nama Counter Legal Draft Kompilasi Hukum Islam (selanjutnya ditulis CLD-KHI) terdapat pasal-pasal yang berlawanan dengan fikih yang selama ini diyakini. ${ }^{1}$

${ }^{1}$ Marzuki Wahid, Fikih Indonesia Kompilasi Hukum Islam dan Counter Legal Draft Kompilasi Hukum Islam Dalam Bingkai Politik Hukum Indonesia, (Bandung: Marja, 2014), 221. 
Setidaknya ada beberapa perubahan dalam KHI yang tercounter di CLD-KHI. Dalam bidang pernikahan ada 18 pembahasan yang dinilai berbeda dengan $\mathrm{KHI}$, dalam hal kewarisan ada 4 pembahasan serta dalam bidang perwakafan ada satu pembahasan. ${ }^{2}$ Jika diakumulasikan ada 23 tema pokok yang terjadi pembaharuan. Pembahasan- pembahasan tersebut mengalami pergantian serta update, misalnya pada perihal pencatatan pernikahan yang dijadikan sebagai rukun pernikahan, wali nikah jadi terhapuskan, pernikahan mut'ah serta pernikahan beda agama diperbolehkan, padahal dalam KHI hal-hal tersebut dengan jelas dilarang.

Pembaharuan tersebut, menurut perumus CLD-KHI, merupakan tantangan untuk menghasilkan pijakan syariat Islam yang menghargai Indonesia dengan segala kepribadian bangsa, kebudayaan, serta realitas sosial yang terjadi pada masyarakat Islam Indonesia. Selain itu juga untuk menjunjung tinggi nilai-nilai demokrasi dan menegakan hak asasi manusia, termasuk hak-hak wanita. Berlandaskan naskah KHI, perumus CLD- KHI mau mengganti kerangka berpikir dalam pembuatan hukum Islam yakni "dari teosentris ke antroposentris, dari elitis ke populis, dari deduktif ke induktif". Pergantian ini dilakukan karena memperhitungkan kenyataan kebudayaan warga Indonesia yang berbeda dengan Timur Tengah. Tidak hanya itu, pula mencermati keadaan banyaknya wanita Indonesia yang saat ini menjadi kepala keluarga serta banyaknya wanita yang turut andil dalam percaturan publik, seperti menjadi pemimpin pemerintahan maupun ketua dalam komunitasnya.

Dalam penjelasannya, tim perumus CLD-KHI berargumen bahwa pembentukan hukum ini berdasarkan semangat hukum Islam yang sesuai dengan perkembangan zaman. Tim CLD-KHI menyatakan ada enam visi hukum yang menjadi dasar, yakni pluralisme ( $\left.t a^{\prime} a d u d i y a h\right)$, nasionalitas (muwathanah), penegakan HAM (iqamat al-huquq al- Insaniyah), demokratis (dimuqrathiyah),

2 Marzuki Wahid, Fikih Indonesia Kompilasi Hukum Islam...., 223-224 
kemaslahatan (maslahat) dan kesetaraan gender (al-musawah aljinsiyah). ${ }^{3}$ Enam prinsip tersebut yang menjiwai keseluruhan aturan dan tawaran hukum Islam yang dirumuskan dalam CLD-KHI.

Sesuai dengan prinsip dan visi yang ditentukan di atas, CLDKHI tidak hanya menawarkan aturan hukum Islam yang berbeda dengan aturan hukum yang sudah ada, tetapi juga mengubah cara pandang terhadap konsep pernikahan, relasi laki-laki dan perempuan, serta konsep perkawinan, perceraian, talak, dan rujuk yang lebih mengarah kepada hubungan yang adil, demokratis dan pluralis, baik antara suami-istri, orang tua dan anak, maupun keluarga dan masyarakat. Konsep ini, lalu memunculkan berbagai kontroversi di kalangan akademisi dan pemerhati hukum, khususnya para ulama' dan pakar dalam bidang hukum Islam. Pihak yang kontra terhadap konsep ini pada umumnya adalah kelompok pejuang formalisasi syariah, sedangkan mereka yang setuju merupakan aktivis kesetaraan dan keadilan gender, pejuang demokrasi, aktivis pluralisme dan Hak Asasi Manusia. Sedangkan untuk para akademisi, mereka banyak yang mengapresiasi konsep CLD-KHI, walaupun hanya sepakat dengan usulan yang dianggap tidak terlalu sensitif. ${ }^{4}$

KHI yang selama ini dianggap sebagai produk ulama fiqh yang statis, rigid, dan kaku perlu diperbaharui dalam membacanya melalui perspektif fiqh kontekstual dengan melakukan upaya pembaharuan hukum Islam di Indonesia. ${ }^{5}$ Selanjutnya, munculnya CLD-KHI sendiri merupakan sebuah iklim dari dinamika hukum yang selalu berkembang di masyarakat seperti persoalan pernikahan sirri, poligami, dan nikah beda agama yang masih mengundang perdebatan sengit di tengah masyarakat Indonesia hingga kini.

Seiring dengan itu, ada konsep maqasid syariah yang digagas oleh Jasser Auda, tokoh pemikir yang getol mengusung gagasan

3 Tim Pengarustamaan Gender Departemen Agama RI, Pembaharuan Hukum Islam: Counter Legal Draft Kompilasi Hukum Islam, (Jakarta, 2004), 25-29.

${ }^{4}$ Marzuki Wahid, Fikih Indonesia Kompilasi Hukum Islam...., 276.

5 Siti Musdah Mulia, Counter Legal Drafting to Islamic Law Compilation (ILC): A Pluralism and Gender Perspective), Icip Journal - Vol 2, No. 3, June 2005.2 
untuk mereformasi pemahaman terhadap filsafat hukum Islam (Ushūl al-Fiqh). Maqasid syariah digunakan Jasser sebagai acuan filosofi berpikir dipadupadankan dengan pendekatan sistem sebagai metode berpikir dan pisau analisis. Pendekatan baru ini, yang mungkin belum pernah terpikirkan oleh pemikir lain, digunakan dalam kajian tentang hukum Islam maupun Ushūl al-Fiqh yang transformatif.

Dalam pendekatan sistem yang ditawarkan Jasser, teradapat enam fitur sistem yang dipakai sebagai alat analisis. Enam fitur tersebut yakni, sistem dimensi kognisi (cognition), sistem kemenyeluruhan (wholeness), sistem keterbukaan (openness), sistem hierarki berpikir yang saling terkait (interrelated hierarchy), sistem berpikir multidimensi (multidimensionality) dan sistem kebermaksudan (purposefullness). Keenam fitur ini, menurut Jasser, sangat saling erat berkaitan dan berhubungan antara satu sistem dan sistem lainnya, sehingga dapat membentuk keutuhan sistem berpikir. ${ }^{6}$

Sistem terakhir, yakni sistem kebermaksudan atau maqasid adalah fitur yang dapat menjangkau semua fitur yang lain dan merepresentasikan inti metodologi analisis sistem tersebut. Jasser meletakan maqasid sebagai prinsip dasar dan metodologi fundamental dalam mereformasi hukum Islam kontemporer yang digaungkan. Jika efektivitas suatu sistem diukur berdasarkan tingkat pencapaian tujuannya, maka efektivitas sistem hukum Islam dinilai berdasarkan tingkat keberhasilan maqasid syariah yang melekat pada aturan tersebut.

Berangkat dari beberapa kegelisahan akademik (sens of crist) di atas bahwa adanya tawaran pembaharuan hukum Islam di Indonesia versi CLD-KHI dan tawaran metode untuk mereformasi hukum Islam agar dapat dinamis menjawab kompleksitas masalah kontemporer versi Jasser Auda melalui maqasid syariah sebagai sebuah pendekatan sistem, maka penulis sangat perlu melakukan

${ }^{6}$ Jasser Auda, Membumikan Hukum Islam Melalui Maqasid Syariah, terj. Rosidin dan Ali Abd el-Mun'im, (Cet. I, Bandung; Mizan. 2015), 251. 
kajian mendalam mengenai kedua tawaran tersebut. Bagaimana tawaran hukum Islam transformatif melalui CLD-KHI jika dilihat dari pendekatan sistem maqasid syariah, serta peluang diterapkan tawaran tersebut dalam percaturan politik hukum di Indonesia. Ini merupakan langkah yang perlu diapresiasi untuk melakukan pembaharuan hukum Islam, terutama hukum keluarga Islam, dalam menjawab perkembangan zaman

\section{METODE PENELITIAN}

Penelitian ini menggunakan metode penelitian kualitatif. Sedangkan untuk jenis penelitiannya adalah Library Research atau penelitian pustaka, yakni dengan mempelajari buku-buku, peraturan perundang-undangan, dan dokumen lain yang memiliki korelasi dengan penelitian ini. Data yang digunakan dalam penelitian ini adalah semua yang berkenaan dengan CLD - KHI dan konsep maqasid syariah Jasser Auda. Pengumpulan data dalam penelitian ini dilakukan dengan cara menelaah mengenai pasal-pasal dalam CLD - KHI, serta konsep pemikiran maqasid syariah jasser Auda. Selain itu, peneliti juga mengumpulkan data mengenai latar belakang penyusunan KHI dan landasan historis perumusan CLD-KHI serta konsep maqasid syariah Jasser Auda.

Langkah peneliti dalam menganilis data adalah sebagai berikut; (a) Pengeditan (Editing), yakni data yang berkenaan dengan KHI, CLD - KHI dan konsep maqasid syariah Jasser Auda dirangkum dan dipilah sesuai dengan fokus penelitian; (b) Klasifikasi (Classifying) dengan cara data yang berkenaan dengan KHI dikelompokan sendiri, sedangkan data yang berkenaan dengan CLD-KHI juga disendirikan. Sedangkan data mengenai konsep maqasid syariah Jasser Auda digunakan untuk menganalisis rumusan yang ditawarkan dalam CLD-KHI; (c) Menganalisa (Analyzing), yakni dengan memaparkan data mengenai CLD-KHI, termasuk data tentang latar belakang, metode istinbath hukumnya dan faktor sosial politik yang melatarbelakangi perumusan CLD-KHI, kemudian peneliti menggunakan teori maqasid syariah Jasser Auda sebagai 
pisau analisis; (d) Menyimpulkan (Concluding), yakni pengambilan kesimpulan dengan cara mengambil poin-poin penting agar dapat menghasilkan gambaran secara ringkas, jelas dan mudah dipahami guna menjawab pertanyaan-pertanyaan yang ada dalam fokus penelitian ini.

\section{HASIL DAN PEMBAHASAN}

Pembahasan dalam artikel ini dibagi berdasarkan fokus penelitian yang telah ditentukan. Fokus penelitian pertama adalah menjawab pertanyaan bagaimana metode istinbath hukum dalam perumusan CLD-KHI. Kemudian fokus penelitian kedua adalah bagaimana rumusan CLD-KHI ditinjau dari perspektif maqasid syariah Jasser Auda. Agar dapat menjawab kedua fokus penelitian tersebut, maka peneliti membahasnya berdasarkan data yang diperoleh dan menganalisanya dengan kerangka teori yang digunakan.

\section{Istinbath Hukum dalam Penyusunan CLD -KHI}

Dalam perumusan CLD KHI terdapat beberapa kerangka metodologi. Abd Moqsith Ghazali menjelaskan bahwa yang pertama dilakukan oleh tim adalah menemukan dan memperbaiki kaidah ushul marjinal yang tidak terliput secara memadai dalam sejumlah kitab kuning. Ghazali menambahkan bahwa terdapat banyak kaidah ushul fikih yang belum difungsikan secara optimal. Kedua, apabila langkah pertama tidak dapat menyelesaikan problem, upaya selanjutnya adalah membongkar paradigma ushul fikih lama dengan cara mengubah paradigma dari teosentrisme ke antroposentrisme. ${ }^{7}$

Dengan cara tersebut, para penafsir berusaha semaksimal mungkin untuk menempatkan teks agama sebagai "obyek" dan dirinya sebagai "subyek" dalam suatu dialektika yang seimbang. Cara lainnya adalah dengan "memfikihkan syariat". Yakni memposisikan syariat sebagai jalan (wasîlah) yang berguna bagi

7 Abd Moqsith Ghazali, Argumen Metodologis CLD-KHI, Kompas, 7 Maret 2005, http://www.kompas.co.id/kompas-cetak/0503/07/swara/1594289.htm 
tercapainya prinsip-prinsip Islam (ghâyat) berupa persamaan, keadilan, kemaslahatan, penegakan HAM. Cara selanjutnya adalah dengan kemaslahatan sebagai rujukan dari seluruh kerja penafsiran. Cara terakhir adalah dengan mengubah gaya berpikir deduktif ke induktif (istiqrầiy). ${ }^{8}$

Selain bangunan metodologi di atas, Counter Legal Draft Kompilasi Hukum Islam (CLD-KHI) merupakan legal draft yang berbentuk pasal-pasal, sehingga dalam proses penyusunanya melalui beberapa kegiatan yang dilakukan secara bertahap, sistematis, dan melibatkan sejumlah pihak yang berkompeten. Langkah-langkah tersebut dianggap perlu untuk menemukan formulasi yang tepat guna merumuskan CLD-KHI secara komprehensif.

Ada beberapa akivitas pokok dalam rangkaian perumusan CLD-KHI. Di antaranya adalah (1) melakukan kajian ulang terhadap KHI-Inpres, (2) studi terhadap literatur klasik Islam, (3) studi lapangan di lima daerah (Sulawesi Selatan, Sumatera Barat, Jawa Barat, Aceh, dan Nusa Tenggara Barat), (4) pengujian ilmiah dan penyerapan pendapat ulama dan ahli hukum, (5) desiminasi hasil dan pengujian publik. Langkah-langkah tersebut dilakukan secara bertahap dan sistematis. ${ }^{9}$

Dengan melalui rangkaian aktivitas tersebut dapat dikatakan bahwa CLD-KHI digali melalui materi pokok KHI-Inpres dengan cara melibatkan serangkaian pengkajian sejarah hukum, politik hukum, sosiologi hukum, dan dekonstruksi ajaran Islam. Selain itu, dilakukan pula pengkajian terhadap literatur, pendapat ahli, kenyataan empiris, dan hukum yang hidup di masyarakat. Serangkaian pengkajian itu dijadikan sebagai pertimbangan penting dalam perumusan CLD-KHI.

Secara sistematis, metodologi yang digunakan dalam merumuskan CLD-KHI adalah sebagai berikut:

8 Abd Moqsith Ghazali, Membangun Ushul Fikih Alternatif, www.islamlib.com, publikasi 24/12/2003.

${ }^{9}$ Marzuki Wahid, Fikih Indonesia Kompilasi Hukum Islam,,, 232. 
1. Kajian Ulang Terhadap Kompilasi Hukum Islam (KHI)

Langkah awal yang dilakukan tim CLD-KHI adalah mereview (mengkaji ulang) KHI-Inpres. Review ini sangat penting guna menentukan masalah apa yang perlu dilakukan dalam rangka perubahan KHI. Oleh karena sejak awal tim ini menjadikan KHIInpres sebagai titik tolak pembaharuan hukum keluarga yang akan dirumuskan, maka review KHI-Inpres menjadi sangat berarti dalam keseluruhan perumusan CLD-KHI.

Tim CLD-KHI memetakan ada 8 (delapan) pokok persoalan yang dipandang penting untuk dikaji dalam kaitan dengan KHIInpres. ${ }^{10}$ Masing-masing poin dikaji oleh setiap tim inti dan dipresentasikan dalam pertemuan tim inti. Terdapat delapan penanggungjawab kajian yang membahas beberapa topik, mereka adalah: (1) Siti Musdah Mulia mengkaji topik Posisi KHI dalam kerangka hukum nasional dan internasional; (2) Marzuki Wahid mengkaji topik KHI dalam perspektif politik hukum; (3) Abd. Moqsith Ghazali mengkaji topik tentang KHI dalam epistemologi ushul fiqh dan kaidah fiqh; (4) Abdurrahman Abdullah mengkaji topik tentang KHI dalam timbangan prinsip-prinsip, nilai dan landasan filsafat hukum Islam; (5) Saleh Partaonan Daulay mengkaji topik mengenai perbandingan pendekatan dalam merumuskan hukum keluarga di Indonesia dan negara-negara Islam lain; (6) Marzani Anwar mengkaji tema tentang masalah-masalah hukum kewarisan, (7) Amirsyah Tambunan mengakaji masalah-masalah hukum perwakafan; dan, (8) Mesraini mengkaji tentang masalahmasalah perkawinan. ${ }^{11}$

Secara substansial, penjelasan delapan topik tersebut tercantum dalam Bab II yang berjudul Menuju Kompilasi Hukum Islam (KHI) Indonesia yang Pluralis dan Demokratis pada buku Pembaharuan Hukum Islam: Counter Legal Draft Kompilasi Hukum Islam. Dalam penjelasannya tampak bahwa tim ini memiliki kritik yang sangat

10 Tim Pengarusutamaan Gender, Pembaharuan Hukum Islam,,,. 7-30.

${ }^{11}$ Marzuki Wahid, Fikih Indonesia Kompilasi Hukum Islam,,, 234. 
tajam terhadap keberadaan KHI-Inpres, mulai dari sejarah penyusunannya yang didominasi oleh eksekutif dan yudikatif, kurang melibatkan partisipasi masyarakat, minimnya keterlibatan perempuan, metodologi pengambilan hukum Islam yang hanya mengambil secara normatif dari tafsir klasik dan mengutip nyaris sempurna pandangan "fiqh purba", hingga kepada materi hukum Islam KHI-Inpres yang dipandang sudah tidak relevan lagi karena tidak mengikuti perkembangan sosial dan regulasi-regulasi lain yang baru. ${ }^{12}$

\section{Studi Literatur Klasik Islam}

Langkah selanjutnya yang dilakukan tim CLD-KHI adalah mengkaji kembali sejumlah literatur klasik Islam sebagaimana yang tercantum dalam Kitab Kuning Pesantren. Ada 41 buah kitab kuning yang dibaca, dianalisis, dan dijadikan rujukan (references) bagi sejumlah rumusan naskah CLD-KHI. Kitab Kuning yang dikaji berasal dari berbagai disiplin ilmu, diantaranya kitab fiqh, kitab tafsir, kitab hadis, kitab qawâ'id al-fiqh, dan kitab ushûl al-fiqh, baik yang ditulis pada abad klasik maupun kontemporer. Pada umumnya kitab-kitab tersebut populer dibaca dan dikaji kalangan pesantren.

Khusus mengenai penggalian hukum yang melahirkan CLD KHI ini, telah dilakukan selama tiga bulan. Pengkajian itu dilakukan secara efektif di kampus Ma'had Aly Situbondo. Tim dipimpin oleh Imam Nakho'i, ${ }^{13}$ kyai muda progresif asal Situbondo, Jawa Timur. Menurut Moqsith, rujukan kitab kuning ini sangat penting, karena meskipun faktanya sudah sangat jelas, tetapi sebagian besar masyarakat Indonesia masih selalu menanyakan rujukan tekstualnya. Hal ini pengaruh kuat dari tradisi yang melekat dalam pembahasan hukum Islam hampir di semua organisasi Islam, terutama di kalangan Nahdlatul Ulama dan Pesantren. Kitab kuning dianggap sebagai rujukan sakral dalam penggalian hukum Islam.

3. Studi Lapangan

12 Marzuki Wahid, Fikih Indonesia Kompilasi Hukum Islam,,, 234.

13 Imam Nakho'i menjabat sebagai Kepala Divisi Pendidikan dan Pengajaran AlMa'had Al-Ali Sukorejo, Situbondo, Jawa Timur. 
Setelah tim CLD-KHI melakukan pemilihan dan pemilahan isu dan masalah pokok yang akan dijadikan sebagai bahan pembaharuan hukum keluarga Islam, tim CLD-KHI juga melakukan kajian lapangan (field research). Penelitian lapangan diposisikan oleh tim CLD-KHI guna menimba dan menggali sebanyak-banyaknya kebijaksanaan (wisdom) dari kehidupan masyarakat Indonesia.

Studi lapangan dilaksanakan di lima tempat, yakni Sumatera Barat, Jawa Barat, Aceh, Nusa Tenggara Barat, dan Sulawesi Selatan. ${ }^{14}$ Pemilihan lima lokasi ini dinilai merepresentasikan pergulatan Islam dengan kebudayaan Indonesia. Kehidupan masyarakat di lima daerah ini dinilai masih kental dengan praktik tradisi lokal bernuansa etnik dalam mengamalkan ajaran keislaman. Misalnya, Jawa Barat dengan budaya Sunda-nya, Sumatera Barat dengan Budaya Minang-nya, Sulawesi Selatan dengan BugisMakasar-nya, Nusa Tenggara Barat dengan Sasak-annya, dan Aceh dengan budaya Aceh-nya.

Riset ini dilakukan selama satu bulan untuk setiap lokasi dan dilakukan dalam waktu yang sama pada Februari - Maret 2004. Selain sebagai bahan dan salah satu metodologi, penelitian lapangan dilakukan untuk mengkonfirmasi atas hasil bacaan kitab kuning mereka, dan juga hasil review mereka terhadap pasal-pasal dalam KHI-Inpres, serta rumusan mereka tentang hukum perdata Islam yang akan ditawarkan kepada publik tersebut.

Abd. Moqsith Ghazali, salah satu anggota Tim CLD-KHI, menjelaskan bahwa hasil temuan lapangan ini adalah salah satu rujukan dan pijakan bagi perumusan CLD-KHI. ${ }^{15}$ Moqsith menerangkan bahwa rujukan materiil CLD-KHI bukan hanya teks Alquran dan al-Hadis serta teks-teks Kitab Kuning, tetapi juga realitas sosial hasil penelitian mereka. Realitas sosial, menurutnya, merupakan kebenaran faktual yang bisa dijadikan sebagai

${ }^{14}$ Marzuki Wahid, Fikih Indonesia Kompilasi Hukum Islam,,, 238.

15 Abd. Moqsith Ghazali, Merancang (Kaidah) Ushul Figh Alternatif, dalam Komarudin Hidayat dan Ahmad Gaus AF eds, Islam, Negara, dan Civil Society: Gerakan dan Pemikiran Islam Kontemporer, (Jakarta: Paramadina. 2005), 38. 
pertimbangan hukum, baik hukum positif (nasional) maupun hukum Islam. ${ }^{16}$

4. Uji Ilmiah dan Dengar Pendapat Ulama \& Para Ahli Hukum

Pengujian ilmiah dan penyerapan pendapat para ulama dan ahli hukum dalam rangkaian perumusan CLD-KHI dilakukan sebanyak empat kali. Pertama dilakukan pada pembahasan naskah akademik (academic paper) atau positioning paper. Ini dilakukan pada 27 Agustus 2003 di Operation Room, Lantai II Depag RI. Pengujian ilmiah dan penyerapan pendapat ini melibatkan berbagai kalangan yang berkepentingan dan memiliki kemampuan untuk memberikan kritik, masukan, dan saran atas rumusan sementara CLD-KHI.

Dalam pengujian ilmiah pertama ini dilakukan oleh Hasanuddin AF (anggota Komisi Fatwa MUI Pusat dan Dekan Fakultas Syari'ah UIN Syarif Hidayatullah Jakarta), Wahyu Widiana (Direktur Badan Pembinaan Peradilan Agama Departemen Agama), dan Ichtijanto SA (mantan perumus KHI-Inpres dan peneliti Balitbang Depag RI). Sementara penyerapan pendapat dilakukan oleh anggota DPR RI, Hakim Agung, pengurus MUI Pusat, pengurus PBNU, pengurus PP Muhammadiyah, pengurus Jama'at Ahmadiyah, pegawai KUA, akademisi dari sejumlah perguruan tinggi Islam, kalangan LSM, dan beberapa orang pembuat RUU HTPA. ${ }^{17}$

Pengujian dan penyerapan yang kedua dilakukan pada 27 Maret 2004 di Jakarta. Berbeda dengan yang pertama, pada pertemuan yang kedua ini hanya dihadiri oleh para kiai, akademisi, aktivis, dan peneliti yang memiliki perhatian pada isu Islam dan gender. Di antara yang hadir pada pertemuan kedua ini adalah Mely G. Tan (peneliti LIPI Jakarta), Andree Feillard (peneliti Centre National de la Recherche Scientifique Prancis), Yanti Mukhtar (aktivis Kapal Perempuan Jakarta), Miftahussurur (aktivis Desantara), Ery Rosatria (aktivis PSW UIN Jakarta), Imam Nakha'i

16 Wawancara yang dilakukan oleh Marzuki Wahid kepada Abd Moqsith Ghazali pada 27 Januari 2009, di Jakarta. Lihat Marzuki Wahid, Fikih Indonesia Kompilasi Hukum Islam,, hlm. 240.

${ }_{17}$ Marzuki Wahid, Fikih Indonesia Kompilasi Hukum Islam,„, 241. 
(pengajar Ma'had 'Aly Situbondo, Jawa Timur), Ratna Batara Munthi (aktivis LBH Apik), KH Husein Muhammad (pengajar Pesantren Darut Tauhid Cirebon), Faqihuddin Abd. Kodir (aktivis Fahminainstitute Cirebon), dan Kamala Chandrakirana (Ketua Komnas Perempuan). Acara ini dipandu oleh Lies Marcoes-Nastir.

Pengujian ilmiah atas draft sementara CLD-KHI ini memunculkan sejumlah kritik dan saran. Di antaranya adalah perlunya konsistensi metodologi yang digunakan, pembacaan terhadap tradisi (Arab dan lokal) kurang empiris, perlunya keseimbangan antara teori dan realitas, perlunya penjelasan semantik untuk terma-terma yang digunakan, perlu mempertegas makna rukun dan syarat nikah, perlu dipertegas makna perkawinan: sakral atau profan, tujuan perkawinan harus dipertegas li tanâsul (bereproduksi) atau sakînah, hidup bersama tanpa nikah (kumpul kebo) tidak bisa diakomodasi, perlu dianalisis lebih jauh nikah mut'ah: siapa yang diuntungkan, pembahasan nikah mut'ah perlu diberi ruang yang cukup dalam beberapa pasal agar tuntas, dan strategi advokasi CLD-KHI harus jelas dan gradual. ${ }^{18}$

Pengujian dan penyerapan yang ketiga dilakukan pada 22-24 April 2004 di Jakarta. Pertemuan ini disebut Forum Ijtihâd Jamâ'iy: Membangun Fiqh Baru Indonesia Berperspektif Jender dan Pluralisme. Jika yang pertama cenderung diikuti birokrat dan penegak hukum, dan yang kedua diikuti aktivis dan peneliti perempuan, maka yang ketiga ini diikuti oleh para ahli dan pakar dalam hukum Islam, baik dari kalangan akademisi, peneliti, aktivis, maupun kyai pesantren.

Pertemuan ini menguji sekaligus menggali argumen-argumen, khususnya argumen teologis, dari setiap poin tawaran pembaharuan hukum keluarga Islam yang telah dirancang tim CLD-KHI. Sebagaimana pada forum sebelumnya, wakil dari tim CLD-KHI memaparkan hasil rumusan sementara, kemudian satu per satu dikaji, dibedah, dan didiskusikan rujukan dalil-dalil syareiyyah-nya. Di sinilah perdebatan dan adu argumentasi terjadi sebagaimana

${ }_{18}$ Marzuki Wahid, Fikih Indonesia Kompilasi Hukum Islam,,, 242. 
forum bahtsul masâ'il di kalangan Nahdlatul Ulama ataupun majlis tarjih di lingkungan Muhammadiyah.

Pengujian ilmiah dan penyerapan pendapat ahli hukum terakhir dilakukan bersama Sumamiharja, SH, pengacara dan legal drafter dari LBH Perjuangan Jakarta. Uji legal drafting ini dilakukan setelah bangunan substansi tawaran pembaharuan hukum keluarga telah bulat disepakati dan pasal-pasal telah ditulis berbentuk Rancangan Undang-Undang (RUU) tentang Hukum Perkawinan Islam, RUU tentang Hukum Kewarisan Islam, dan RUU tentang Hukum Perwakafan Islam. Forum ini dilaksanakan pada 7 Juli 2004 di Jakarta untuk menyelaraskan logika, sistematika, dan redaksi hukum dari draft CLD-KHI. ${ }^{19}$

5. Desiminasi Hasil dan Pengujian Publik.

Desiminasi hasil dan pengujian publik merupakan terminal akhir bagi tim CLD-KHI untuk melepaskan hasil rumusannya ke wilayah publik. Forum ini dinamakan Diskusi dan Launching Counter Legal Draft KHI diselenggarakan di Hotel Aryaduta Jakarta pada 4 Oktober 2004. Launching naskah CLD-KHI dilakukan oleh Menteri Agama RI, Said Aqil Husin Almunawwar. Bersamaan dengan launching juga diselenggarakan diskusi publik dengan narasumber Abd. Moqsith Ghazali dan Marzuki Wahid (dari tim CLD-KHI).

Siti Musdah Mulia, Ketua Pokja Pengarusutamaan Gender, memberikan pengantar pada awal pertemuan tentang CLD-KHI dengan segala maksud, tujuan, proses, dan hasil yang diperoleh. Adapun moderator pada sesi pertama Ulil Abshar-Abdalla (Jaringan Islam Liberal) dan pada sesi kedua Ratna Batara Munti (Lembaga Bantuan Hukum APIK). Launching ini diikuti oleh sekitar 200 peserta dari berbagai unsur: pemerintah, DPR, Mahkamah Agung, hakim, Ormas Islam, LSM, aktivis perempuan, Komnas HAM, Komnas Perempuan, MUI, Pesantren, wartawan, dan lain-lain.

${ }^{19}$ Marzuki Wahid, Fikih Indonesia Kompilasi Hukum Islam,„, 244. 


\section{CLD-KHI dalam Tinjauan Maqasid Syariah Jasser Auda}

Jaseer Auda mengusulkan pendekatan sistem terhadap teori hukum Islam kontemporer dan menyajikan beberapa usulan yang dapat meningkatkan keterbukaan dan kebermaksudan hukum Islam. Jasser Auda menganggap bahwa ushul fikih (dasar hukum Islam) adalah sebuah sistem. Sebagai suatu sistem, akan dianalisis berdasarkan 6 fitur dari pendekatan sistem. Keenam fitur sistem yang disusun oleh Jasser Auda adalah sistem kognitif, sistem keutuhan, sistem keterbukaan, sistem interrelasi hierarkis, sistem multidimensi, dan sistem berorientasi pada tujuan. Keenam fitur ini akan digunakan untuk menganalisis pembentukan CLD-KHI. Penjelasan keenam fitur diatas beserta analisis terhadap perumusan CLD-KHI akan diuraikan sebagai berikut:

1. Sifat Kognitif dari Sistem Hukum Islam

Dari perspektif teologis Islam, hukum Islam atau fiqh merupakan hasil dari nalar manusia, refleksi (ijtihad) terhadap nash/teks untuk mengungkapkan makna tersirat atau implikasi praktis dari teks keagamaan. Fiqh semata-mata bagian dari kognisi manusia (idrak) dan pemahaman manusia (fahm), bukan manifestasi literal dari perintah Allah. Fiqh berbeda dengan syariah. Jika syariah sifatnya mutlak, maka fiqh bersifat dzony (sangkaan). Sehingga, kebenaran fiqh bersifat sementara (dinamis).

KHI atau fikih Indonesia, adalah hasil dari ijtihad cendekiawan Indonesia, bukan Syariat Allah yang tidak dapat diubah. Karena itu, ketika yurisprudensi dianggap tidak lagi relevan dengan tuntutan zaman itu perlu dilakukan pembaharuan dengan cara ijtihad. Ijtihad yang dilakukan oleh tim CLD-KHI adalah langkah, yang jika dikaitkan dengan sistem kognisi, adalah upaya untuk merekonstruksi pemahaman tentang fiqh, yang merupakan persepsi dan interpretasi para ulama, dapat berubah seiring perubahan waktu, tempat dan keadaan.

Ijtihad tersebut perlu dilakukan, mengingat $\mathrm{KHI}$, menurut tim CLD-KHI, sudah tidak lagi relevan dengan kondisi terkini. Misalnya soal kedudukan suami-istri dalam keluarga, pencatatan perkawinan, 
batas minimal usia perkawinan, kesaksian perempuan dalam perkawinan, poligami, iddah, ihdad, nusyuz, dan lain-lain.

2. Keutuhan/Kemenyeluruhan Sistem Hukum Islam

Menurut Jasser Auda, saat ini seorang peneliti ilmu alam dan peneliti ilmu-ilmu sosial telah mengalami pergeseran secara luas menuju penjelasan semua fenomena dalam sistem holistik. Jadi dalam pandangan Jasser Auda tentang mengembangkan cara berpikir holistik dan sistematis dalam konteks pengembangan ushul al-fiqh sangat membantu. Berdasarkan argumen teologis dan rasional ternyata bukti holistik (al-dalil al-kulli) dapat dipertimbangkan lebih kuat dalam ushul al-fiqh daripada parsial. Selain mengembangkan ushul-fiqh, pendekatan holistik juga berguna untuk pengembangan filsafat agama ('ilm al-kalâm). Secara implisit Jasser Auda menekankan pentingnya penguasaan ilmu alam dan ilmu sosial. ${ }^{20}$

Dalam konsep formulasi CLD-KHI, fitur keutuhan yang disebutkan di atas telah terpenuhi. Tim CLD-KHI dalam melihat argumen dilakukan secara menyeluruh. Dalam pengkajian terhadap Alquran dan hadis misalnya, tim CLD-KHI melakukannya berdasarkan tema-tema yang telah dikelompokan, baik berupa kitabkitab tafsir maupun kitab hadis. Kemudian dikaji secara tematik melalui kajian tafsir maudhui. ${ }^{21}$ Selain mengambil proposisi Al Qur'an dan hadis, tim CLD KHI juga meninjau sejumlah literatur klasik Islam seperti yang dilakukan di pesantren. Ada 41 buku klasik Islam yang dibaca, dianalisis dan dijadikan referensi untuk sejumlah penawaran reformasi hukum keluarga Muslim dari tim CLD KHI. Buku klasik Islam (kitab kuning) yang dipelajari adalah fiqh, tafsir, hadis, qawaid al-fiqh, dan ushul fiqih, keduanya ditulis pada abad klasik dan kontemporer.

Selain itu, mereka juga melakukan studi langsung di lapangan yang dilakukan di empat lokasi, yaitu Sulawesi Selatan, Sumatera

20 Jasser Auda, Membumikan Hukum Islam Melalui Maqasid Syariah, terj. Rosidin dan Ali Abd el-Mun'im,,,260.

21 Tim Pengarustamaan Gender Departemen Agama RI, Pembaharuan Hukum Islam,,, 25. 
Barat, Jawa Barat, dan Nusa Tenggara Barat. Keempat lokasi tersebut merepresentasikan perjuangan Islam dengan budaya Indonesia karena keempat bidang kehidupan masyarakat ini masih cukup kuat untuk mengikuti tradisi lokal nuansa etnis dalam praktek ajaran Islam.

3. Keterbukaan Sistem Hukum Islam

Keterbukaan sistem dalam hukum Islam bisa dibuktikan bahwa dalam teori sistem dibedakan menjadi sistem terbuka dan tertutup. Sistem kehidupan adalah sistem terbuka.. Menurut teori Bertalanffy, bahwa sistem terbuka memiliki kemampuan untuk memperoleh objektivitas yang sama dari kondisi awal yang berbeda melalui jalan keluar yang sah dan valid. Jadi sistem terbuka sangat interaktif dengan lingkungan di luar sistem, tidak seperti sistem tertutup yang terisolasi dari dunia luar. ${ }^{22}$

Sistem hukum Islam termasuk sistem terbuka. Hal itu dapat kita lihat dari terbukanya pintu ijtihad terhadap hukum Islam. Semua lembaga yurisprudensi Islam, bagaimanapun, dan sebagian besar fuqoha (ahli fiqh) percaya bahwa ijtihad sangat diperlukan untuk merumuskan hukum Islam, karena teks (Alquran) sangat terbatas sedangkan peristiwa manusia tidak terbatas dan selalu dinamis.

Dengan demikian, metodologi hukum Islam telah menerapkan aturan pasti untuk beradaptasi dengan perkembangan zaman. Dalam terminologi teori sistem, inilah yang disebut interaksi dengan lingkungan (interaktif) dan tidak terisolasi. Contoh mekanisme tersebut adalah penalaran analogis (qiyas), maslahah, dan mengakomodasi adat istiadat setempat (i'tibar urf). Namun, dapat dilihat bahwa mekanisme seperti ini memerlukan pengembangan lebih dalam lagi untuk membuat hukum Islam dapat diterima sesuai dengan perkembangan zaman. Dengan demikian sifat hukum Islam tidak lagi tertutup, tetapi termasuk dalam sistem hukum yang terbuka.

22 Jasser Auda, Membumikan Hukum Islam Melalui Maqasid Syariah, terj. Rosidin dan Ali Abd el-Mun'im,,,. 263 
Nilai keterbukaan tersebut diterapkan dalam proses perumusan CLD-KHI. Ini bisa dilihat dalam ijtihad tim CLD-KHI, mereka telah mengimplementasikan fitur ini. Mereka menyadari bahwa hukum Islam (fiqh) harus dilihat secara terbuka. Sehingga ketika ada kebutuhan untuk pembaharuan dan penyesuaian yang didasari pada konteks, waktu, dan keadaan sosial, maka fikih Indonesia (KHI) harus dilihat secara terbuka pula. Misalnya, telah ditemukan pasal-pasal dalam KHI yang memarginalkan hak asasi manusia dan perempuan, maka pasal-pasal tersebut perlu dikaji sesuai dengan konteks tanpa meninggalkan teks pijakannya.

\section{Hierarki-terkait Sistem Hukum Islam}

Sistem interlasi hierarkis (hierarki-terkait) memberikan makna bahwa dalam sistem hukum Islam terdapat keterkaitan yang bersambung. Sistem ini menunjukan perbaikan pada dua dimensi maqasid. Pertama, peningkatan rentang maqasid. Jika pemahaman sebelumnya, studi maqasid bersifat khusus, maka fitur ini mengklasifikasikan maqasid berdasarkan pada hierarkis yaitu; maqasid umum (studi semua bagian hukum Islam), maqasid khusus (studi pengamatan seluruh isi hukum Islam tertentu, dan maqasid tertentu (penurunan nash atau hukum tertentu). Perbaikan dimensi kedua adalah peningkatan jangkauan dari orang yang dicakup oleh maqasid. Jika maqasid selama ini hanya mencapai objek individu, maka fitur ini membuat maqasid dapat menjangkau objek yang lebih luas, yakni merambah ke dimensi sosial dan publik. ${ }^{23}$

Penerapan jangkauan maqasid dari individu ke dimensi sosial publik dalam rumusan CLD-KHI dapat dilihat dari penggunaan semangat pluralisme (ta'adudiyah), kebangsaan (muwâthanah), penegakan hak asasi manusia (iqâmat al-huquq al-Insâniyah), demokratis (dimuqrâthiyah), kemaslahatan (maslahat), dan kesetaraan jender (al-musawah al-jinsiyah) dalam prinsip dan visi hukumnya. Misalnya, dalam pasal tentang batas minimal perkawinan. KHI mengatur batas minimal perkawinan bagi calon

23 Jasser Auda, Membumikan Hukum Islam Melalui Maqasid Syariah, terj. Rosidin dan Ali Abd el-Mun'im,,, 268. 
isteri adalah 16 tahun dan minimal 19 tahun bagi calon suami (pasal 15). Sedangkan dalam rumusan CLD-KHI mengaturnya dalam pasal 7 bahwa minimal usia perkawinan adalah 19 tahun baik untuk usia calon isteri maupun usia calon suami. ${ }^{24}$

5. Multidimensionalitas Sistem Hukum Islam

Sistem bukan berasal dari sesuatu yang tunggal dan berdiri sendiri. Namun, sistem merupakan gabungan dari beberapa bagian yang saling terkait satu sama lain. Suatu sistem terdiri dari beberapa bagian yang cukup kompleks, sehingga memiliki spektrum dimensi yang tidak tunggal. Sejalan dengan sistem semacam itu, hukum Islam juga dapat dikatakan memiliki banyak dimensi. Hukum Islam tidak berjalan tunggal, melainkan terdiri dari banyak spektrum yang mengitari. ${ }^{25}$

Hukum Islam merupakan sistem yang memiliki banyak dimensi. Prinsip inilah yang digunakan oleh Jasser Auda untuk mengkritik akar pemikiran oposisi biner dalam hukum Islam. Menurut Jasser, paradigma biner oposisi harus dihilangkan untuk menghindari pengurangan metodologis, serta mendamaikan adanya pertengkaran argumen yang berjalan bertentangan, dengan cara mengedepankan aspek maqasid (tujuan hukum). Misalnya, jika terjadi perbedaan proposisi dalam aturan tentang ibadah yang muncul harus dilihat dari maqasid li taysir (memudahkan), perbedaan dalam hadis yang berkaitan dengan 'urf harus dilihat dari perspektif maqasid dari universalitas hukum, dan keberadaan naskh harus dilihat sebagai penetapan hukum secara bertahap. Tim CLD KHI berusaha keluar dari dikotomi hukum tersebut. Mereka ingin membawa hukum sesuai dengan kebutuhan dan tuntutan zaman dengan melihat multidimensionalitas hukum Islam.

6. Tujuan (Kebermaksudan) Sistem Hukum Islam

24 Batas usia minimal pernikahan ini sudah diakomodasi dalam UU Perkawinan terbaru yang mengatur bahwa usia minimal 19 tahun bagi calon suami maupun calon isteri.

25 Jasser Auda, Membumikan Hukum Islam Melalui Maqasid Syariah, terj. Rosidin dan Ali Abd el-Mun'im,,, 276. 
Tujuan hukum (maqasid) adalah fitur yang mencakup lima fitur sebelumnya, sehingga tujuan inilah yang menjadi metodologi inti dari analisis sistematis di atas. Penerapan maqasid adalah dasar yang sangat penting dan fundamental untuk keberlangsungan sistem hukum Islam yang hendak dikaji. Penggalian terhadap maqasid juga harus dikembalikan ke teks utama (Alquran dan hadis), bukan pendapat atau pikiran faqih (produk ijtihad). Dengan demikian, realisasi tujuan (maqasid) akan menjadi tolok ukur keabsahan setiap ijtihad, tanpa mengkaitkan dengan kecenderungan atau mazhab tertentu. Selain itu, dan ini yang paling utama, bahwa tujuan dari hukum Islam harus difokuskan kepada kesejahteraan masyarakat sekitar. ${ }^{26}$

Kita dapat memahami bersama bahwa ide segar Jasser Auda yang menawarkan filosofi sistem sebagai pendekatan dalam pengembangan studi maqasid ini, secara tidak langsung mendorong umat Islam untuk melek dengan bangunan studi episteme dari maqasid sebelumnya yang sudah "usang", perlu suatu kontekstual ijtihad yang segar sehingga sistem hukum Islam dapat diterapkan sesuai dengan tuntutan zaman dan mampu mengakomodasi dan membawa solusi yang tepat terhadap sasaran semua masalah manusia yang semakin kompleks. Dalam ide ini, Jasser Auda ingin menekankan bahwa tujuan hukum Islam (maqasid syariah) adalah tujuan utama dari semua bangunan metodologi linguistik dan rasional ijtihad.

Proses ijtihad inilah yang mendorong tim CLD-KHI menggunakan bangunan episteme yang baru dalam merumuskan legal draft tersebut. Proses usaha tersebut untuk mewujudkan maqasid dalam hukum Islam, serta ingin menyajikan penawaran hukum transformatif guna mengatasi masalah hukum yang semakin kompleks.

Dari fitur-fitur di atas dapat dilihat adanya perubahan paradigma dalam penggunaan perspektif maqasid dalam studi

${ }^{26}$ Jasser Auda, Membumikan Hukum Islam Melalui Maqasid Syariah, terj. Rosidin dan Ali Abd el-Mun'im,,, 294. 
hukum Islam. Perubahan paradigma tersebut terlihat pada fokus utama dan titik tekan maqasid itu sendiri. Jika titik tekan maqasid lama lebih pada perlindungan dan penjagaan/pelestarian, maka titik tekan dan inti dari teori maqasid baru lebih menekankan pembangunan/pengembangan dan hak asasi.

Counter Legal Draft Kompilasi Hukum Islam (CLD-KHI) menggunakan paradigma baru pada proses penyusunannya. Itu terlihat dari pasal-pasal yang ditawarkan menunjukan dan berpihak pada hak-hak asasi manusia dan perempuan. Namun demikian, CLD KHI menuai banyak kontroversial karena dianggap sesat, bid'ah, serta merubah keaslian hukum Islam yang selama ini ada, dan telah melakukan pemanipulasian nash-nash Alquran. Perdebatan pun muncul hingga berujung pada pembekuan oleh Menteri Agama, Maftuh Basyuni, pada 26 Oktober 2004, di Kantor MUI, Jakarta Pusat. Pembekuan tersebut hanya melalui pernyataan di media massa dan tidak disertai surat resmi.

Kalau kita cermati lebih mendalam, CLD-KHI secara konseptual telah berhasil memadukan hukum Islam dengan kenyataan yang selama ini ada, seperti demokrasi, pluralisme, hak asasi manusia, dan keadilan gender, baik dalam tataran metodologi maupun rumusan yang ditawarkan dalam pasal-pasal yang ada. Meskipun secara legislasi, tim CLD-KHI telah gagal meyakinkan pemerintah, DPR dan sebagian besar tokoh-tokoh Islam, tawarantawaran hukum transformatif dalam KHI merupakan langkah progresif untuk "mengindonesiakan" hukum Islam dalam konteks terkini.

\section{KESIMPULAN}

Dari pemaparan di atas, penulis dapat menarik benang merah bahwa Counter Legal Draft Kompilasi Hukum Islam (CLD-KHI) merupakan legal draft (naskah hukum) yang berbentuk pasal-pasal. Proses perumusannya melalui beberapa kegiatan yang dilakukan secara bertahap, sistematis, dan melibatkan beberapa pihak yang berkompeten di bidangnya. Ada beberapa tahapan dalam rangkaian 
perumusan CLD-KHI tersebut, yaitu pertama, mengkaji ulang KHIInpres. Kedua, melakukan studi terhadap literatur klasik Islam. Ketiga, mengadakan kajian lapangan di lima lokasi (Sulawesi Selatan, Sumatera Barat, Jawa Barat, Aceh, dan Nusa Tenggara Barat). Keempat, melakukan uji ilmiah dan dengar pendapat para ulama dan ahli hukum. Kelima, mengadakan desiminasi hasil dan pengujian publik. Langkah-langkah tersebut dilakukan secara bertahap dan sistematis.

Dengan langkah prosedural dan didukung oleh hasil analisis di atas, maka Counter Legal Draft Kompilasi Hukum Islam (CLD-KHI) tidak bertentangan dengan maqasid syariah Jasser Auda. Jika ditinjau menggunakan enam fitur teori sistem yang digagas Jasser Auda, yakni sistem kognitif, sistem keterbukaan, sistem kemenyeluruhan, sistem interelasi hirearki, sistem multidimensional dan sistem kebermaksudan, maka proses perumusan CLD KHI sesuai dengan fitur-fitur tersebut. Namun untuk melegalkan tawaran tersebut dan menggantikan KHI-Inpres masih terhalang oleh faktor politik, karena terdapat pasal-pasal yang dianggap kontroversial.

Setelah melakukan kajian terhadap Counter Legal Draft Kompilasi Hukum Islam (CLD-KHI) menggunakan analisis maqasid syariah Jasser Auda, penulis kiranya perlu memberikan saran dan rekomendasi kepada berbagai pihak; (1) Pemerintah, dalam hal ini Kementerian Agama, yang telah membekukan draft CLD KHI untuk melakukan pengecekan ulang terhadap naskah tersebut. CLD KHI merupakan langkah transformatif untuk mereformasi hukum perdata Islam di Indonesia, khususnya KHI yang telah berumur lebih dari 27 tahun, agar hukum Islam tetap up-to-date menjawab permasalahan yang semakin kompleks; (2) Tim CLD-KHI bisa melakukan kompromi kepada seluruh pihak terkait untuk merevisi pasal-pasal yang dianggap kontroversial agar dapat diterima oleh semua kalangan. Dengan mengajak diskusi tokoh-tokoh agama dari berbagai aliran dan ormas, akademisi, politisi dan pemangku kebijakan, serta para pihak (aktivis) yang konsern memperjuangkan keadilan dan kesetaraan gender, hak asasi manusia (HAM), 
demokrasi dan pluralisme tawaran hukum transformatif pada pasalpasal dalam CLD-KHI dapat diterima dan; (3) Bagi kalangan akademisi dan peneliti agar melakukan kajian lebih dalam mengenai tawaran hukum transformatif CLD-KHI, supaya hukum perdata Islam, khususnya hukum keluarga Islam, di Indonesia tidak bias gender. Karena dalam pasal-pasal yang ada dalam hukum perkawinan Islam, baik UU No.1/1974 maupun Kompilasi Hukum Islam (Inpres No. 1/1991), masih menunjukan ketidakadilan gender.

\section{DAFTAR PUSTAKA}

Auda. Jasser, Membumikan Hukum Islam Melalui Maqasid Syariah, terj. Rosidin dan Ali Abd el-Mun'im, Cet. I, Bandung; Mizan. 2015. Darwis, Rizal. Pemikiran Ibnu Qayyim al-Jauziyah Terhadap Paradigma Perubahan Hukum, Jurnal Hukum dan Ekonomi Syariah, Adzkiya', Vol. 5, No. 1, 2017.

Ghazali, Abd Moqsith. Argumen Metodologis CLD-KHI, Kompas, 7 Maret 2005, http://www.kompas.co.id/kompascetak/0503/07/swara/1594289.htm

Ghazali, Abd Moqsith. Membangun Ushul Fikih Alternatif, www.islamlib.com, publikasi 24/12/2003.

Ghazali, Abd. Moqsith. Merancang (Kaidah) Ushul Figh Alternatif, dalam Komarudin Hidayat dan Ahmad Gaus AF eds, Islam, Negara, dan Civil Society: Gerakan dan Pemikiran Islam Kontemporer, Jakarta: Paramadina. 2005.

Hidayat, Komarudin dan Ahmad Gaus AF eds, Islam, Negara, dan Civil Society: Gerakan dan Pemikiran Islam Kontemporer, Jakarta: Paramadina, 2005.

Mulia, Siti Musdah, Counter Legal Drafting to Islamic Law Compilation (ILC): A Pluralism and Gender Perspective), Icip Journal - Vol 2, No. 3, June 2005. 
Tim Pengarustamaan Gender Departemen Agama RI, Pembaharuan Hukum Islam: Counter Legal Draft Kompilasi Hukum Islam. Jakarta, 2004.

Wahid, Marzuki. Fikih Indonesia Kompilasi Hukum Islam dan Counter Legal Draft Kompilasi Hukum Islam Dalam Bingkai Politik Hukum Indonesia, Bandung: Marja. 2014. 